\title{
Fish predation on the scleractinian coral Madracis mirabilis controls its depth distribution in the Florida Keys, USA
}

\author{
A. G. Grottoli-Everett*, G. M. Wellington \\ Department of Biology and Biochemistry, University of Houston, Houston, Texas, 77204-5513, USA
}

\begin{abstract}
We evaluated the role of fish predation as the mechanism controlling the local distribution of the scleractinian coral Madracis mirabilis on Conch Reef in the Florida Keys, USA. At many Caribbean sites, $M$. mirabilis is found at depths ranging from 1 to $63 \mathrm{~m}$. However, at Conch Reef this coral is rarely found shallower than $20 \mathrm{~m}$. M. mirabilis fragments transplanted from 26 to $13 \mathrm{~m}$ depth suffered significantly higher levels of fish predation than fragments transplanted from 26 to $20 \mathrm{~m}$. These results indicate that fish predation potentially limits the vertical distribution of $M$. mirabilis on Caribbean reefs.
\end{abstract}

KEY WORDS: Fish predation - Coral distribution Madracis mirabilis

Competition for space, habitat type, food availability, environmental conditions and natural disturbances have often been emphasized as important factors controlling coral distribution (Loya 1972, Porter 1972, 1974, 1976, Fishelson 1973, Lang 1973, Glynn 1976, 1988, Sammarco 1980, 1982, Wellington 1982a, Huston 1985, Glynn \& Colgan 1988). Increasing evidence from field studies shows that predation by invertebrates (Robertson 1970, Glynn et al. 1972, 1979, Glynn 1976, McClanahan \& Shafir 1990, McClanahan et al. 1996) and corallivorous reef fish (Glynn et al. 1972, Kaufman 1977, Brock 1979, Neudecker 1979, Wellington 1982b, Harmelin-Vivien \& Bouchon-Navaro 1983, Littler et al. 1989) can play a direct role in shaping coral distribution and community structure (reviewed by Glynn 1990, Hixon 1997). Here, we present evidence that fish predation limits vertical distribution of the pocilloporid coral Madracis mirabilis on the Florida, USA reef tract.

Madracis mirabilis is commonly found throughout the Caribbean, South Florida and the Bahamas (Hu-

•E-mail: bioldr@jetson.uh.edu mann 1993). It forms densely packed clumps of small pencil-sized branches with blunt tips, small polyps which are light brown to yellow in appearance. $M$. mirabilis is found nearshore at a depth of $3 \mathrm{~m}$ at the Channel Two pass $\left(24^{\circ} 50^{\prime} 05^{\prime \prime} \mathrm{N}, 81^{\circ} 41^{\prime} 05^{\prime \prime} \mathrm{W}\right)$ which links Florida Bay and the Florida reef track between Lower Matacumbe Key and Long Key (pers. obs.). At Conch Reef, Florida (24 $57^{\prime} 05^{\prime \prime} \mathrm{N}, 80^{\circ} 28^{\prime} 00^{\prime \prime} \mathrm{W}$ ), it is rarely found shallower than $20 \mathrm{~m}$. In the course of experimentally assessing the source of carbon in the skeletal matrix of $M$. mirabilis, we observed evidence of heavy fish grazing on colonies transplanted from 26 to $13 \mathrm{~m}$ depth.

In this experiment, 8 distinct Madracis mirabilis coral colonies were collected at $26 \mathrm{~m}$ and each was divided into 8 fragments. Each individual fragment was cemented to an individual plexiglass disk. Four fragments from each coral head were transplanted to $13 \mathrm{~m}$ and 4 to $20 \mathrm{~m}$ ( 4 fragments colony ${ }^{-1} \times 2$ depths $x$ 8 colonies $=64$ total sample size). All fragments were manipulated in an identical fashion at both depths. Coral fragments were collected approximately $6 \mathrm{wk}$ later and treated in 5\% sodium hypochlorite solution for $24 \mathrm{~h}$. Because the number of branches per fragment was unequal, predation is reported here as a percentage, as follows:

$$
\frac{\text { total number of fish bites }}{\text { (total number of branches/fragment) }} \times 100 \%
$$

In cases where the total number of bites exceeded the total number of branches (due to more than 1 bite/ branch ${ }^{-1}$ ) the percent predation value exceeded 100 .

Overall mean percent predation was found to be significantly greater at $13 \mathrm{~m}$ than at $20 \mathrm{~m}$ (Table 1 ). With the exception of colony 2 , the mean percent predation was consistently higher in shallow water. In some shallow water fragments, all branch tips were bitten off, yet none of the fragments in deeper water were in such 
Table 1. Madracis mirabilis. Mean percent predation per colony at each depth $(n=3$ for colony 2 at $13 \mathrm{~m}$ and $n=4$ for all other colonies at both depths). Mean percent predation was significantly higher at $13 \mathrm{~m}$ than at $20 \mathrm{~m}$ (Wilcoxon's signed-ranks test $T_{\mathrm{s}}=2, \mathrm{n}=8, \mathrm{p}<0.0117$ )

Colony Mean percent predation Mean percent predation at $13 \mathrm{~m} \quad$ at $20 \mathrm{~m}$

\begin{tabular}{|ccc}
\hline 1 & 61 & 0 \\
2 & 7 & 28 \\
3 & 125 & 21 \\
4 & 108 & 26 \\
5 & 1.02 & 29 \\
6 & 75 & 17 \\
7 & 37 & 32 \\
8 & 83 & 10 \\
Mean of means & 74.75 & 20.38 \\
SE & 12.90 & 3.61 \\
\hline
\end{tabular}

condition (Fig. 1). These results indicate that at Conch Reef predation by corallivorous fish plays a critical role in restricting the distribution of Madracis mirabilis to depths below $13 \mathrm{~m}$. Although we did not directly observe fish predation on $M$. mirabilis since caged controls were not employed in this experimental design, the cusp-like bite marks revealed that parrotfish and/ or pufferfish are likely to be responsible. No other evidence of damage due to handling or predation by other organisms was observed.

Situations where fish predation limits the zonation patterns of corals have also been reported in the branching coral Pocillopora damicornis (Neudecker 1979, Wellington 1982b) and massive Pavona spp. (Wellington 1982b) in the Pacific, for Montastraea annularis and Acropora cervicornis in Jamaica (Kaufman 1977) and for Porites astreoides and Porites porites furcata in Belize (Littler et al. 1989). The pattern of predation observed in this study was also reported by Neudecker (1979) for P. damicornis. Further, Littler et al. (1989) suggested that the degree of fish predation is influenced by proximity to refugia for the corallivores and coral palatability. However, these factors do not appear to be applicable to Conch Reef where topographic complexity and refugia increase with depth (pers, obs.) in opposition to the observed increase in predation across the experimental depth, and where deep water $M$. mirabilis is susceptible to predation when transplanted to shallower depths

Field studies examining the direct role of corallivorous fishes on coral zonation are limited (Kaufman 1977, Neudecker 1979, Wellington 1982b, Littler et al. 1989, reviewed by Glynn 1990, Hixon 1997). Our observations provide further evidence that fish predation can be an important factor limiting the vertical distribution of reef corals.

Acknowledgements. We thank the staff of the National Undersea Research Center's Florida Keys Program (UNCW) for their support during 'Aquarius' mission No. 17 and the Jason Foundation for Education (Jason Project VII) for financial assistance. For their assistance in the field we thank K. Sebens, G. Taylor, K. Wood and D. J. Roller. We also thank Dr C. Birkeland and 3 anonymous reviewers for their helpful comments on the manuscript.

\section{LITERATURE CITED}

Brock RE (1979) An experimental study of the effects of grazing by parrotfishes and role of refuges in benthic community structure. Mar Biol 51:381-388

Fishelson L (1973) Ecological and biological phenomena influencing coral-species composition on the reef tables at Eilat (Gulf of Acqaba, Red Sea). Mar Biol 19:183-196

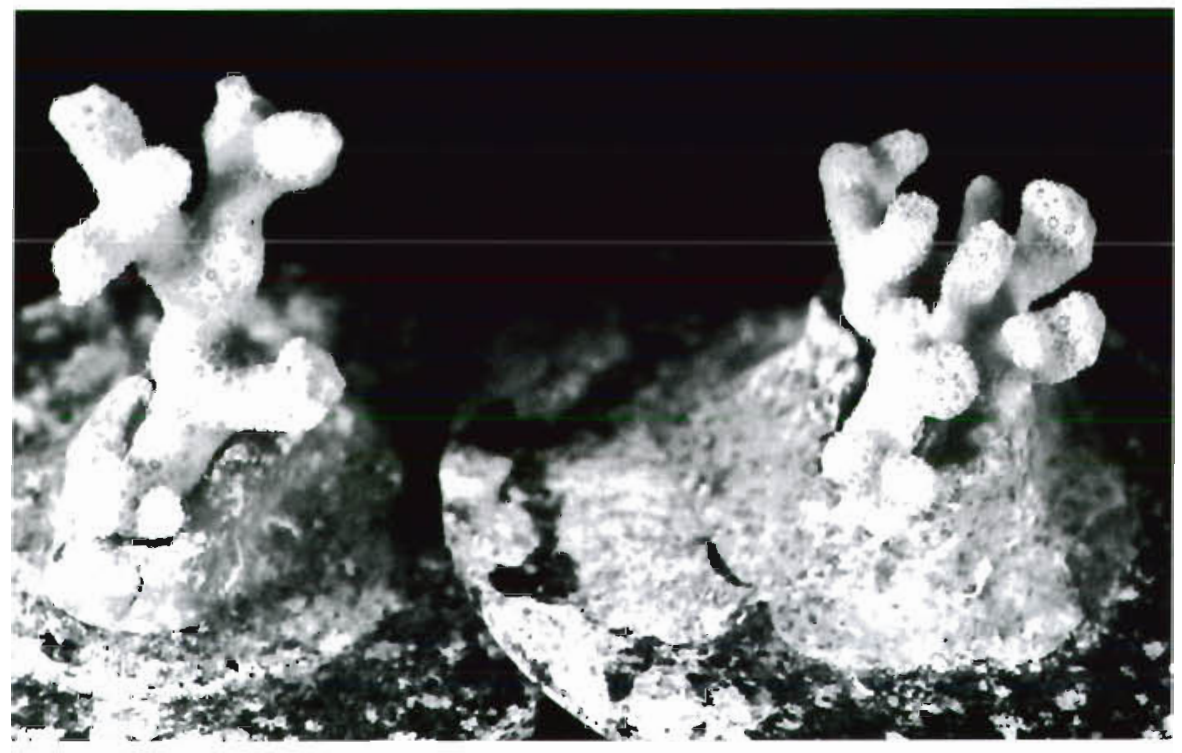

Fig. 1. Madracis mirabilis fragments: from $13 \mathrm{~m}$ with branch tips bitten off (on left) and from $20 \mathrm{~m}$ with intact branch tips (on nght) 
Glynn PW (1976) Some physical and biological determinants of coral community structure in the Eastern Pacific. Ecol Monogr 46:431-456

Glynn PW (1988) El Niño-Southern Oscillation 1982-83: nearshore population, community and ecosystem responses. Annu Rev Ecol Syst 19:309-345

Glynn PW (1990) Feeding ecology of selected coral-reef macroconsumers; patterns and effects on coral community structure. In: Dubinsky Z (ed) Ecosystems of the world 25: Coral reefs. Elsevier, Amsterdam, p 365-400

Glynn PW, Colgan MW (1988) Sporadic disturbances in fluctuating coral reef environments: El Niño and coral reef development in the Eastern Pacific. Am Zool 32:707-718

Glynn PW, Stewart RH, McCosker JE (1972) Pacific coral reefs of Panama: structure, distribution and predators. Geol Rundsch 61:483-519

Glynn PW, Wellington GM, Birkeland C (1979) Coral reef growth in the Galapagos: limitation by sea urchins. Science 203:47-49

Harmelin-Vivien ML, Bouchon-Navaro Y (1983) Feeding diets and significance of coral feeding among Chaetodontid fishes in Moorea (French Polynesia). Coral Reefs 2: $119-127$

Hixon MA (1997) Effects of reef fishes on corals and algae. In: Birkeland C (ed) Life and death of coral reefs. Chapman and Hall, New York, p 231-246

Humann P (1993) Reef coral identification. New World Publications, Inc, Jacksonville

Huston MA (1985) Patterns of species diversity on coral reefs. Annu Rev Ecol Syst 16:149-177

Kaufman L (1977) The three spot damselfish: effects on benthic biota of Caribbean coral reefs. Proc 3rd Int Coral Reef Symp 1:559-564

Lang $J$ (1973) lnterspecific aggression by scleractinian corals. 2. Why the race is not only to the swift. Bull Mar Sci 23: $260-279$

Editorial responsibility: Charles Birkeland (Contributing Editor), Mangilao, Guam
Littler MM, Taylor PR, Littler DS (1989) Complex interactions in the control of coral zonation on a Caribbean reef flat. Oecologia 80:331-340

Loya Y (1972) Community structure and species diversity of hermatypic corals at Eilat, Red Sea. Mar Biol 13:100-123

McClanahan TR, Kamukuru AT, Muthiga NA, Gilagabher Yebio M. Obura D (1996) Effect of sea urchin reductions on algae, coral and fish populations. Conserv Biol 10 : $136-154$

McClanahan TR, Shafir SH (1990) Causes and consequences of sea urchin abundance and diversity in Kenyan coral reef lagoons. Oecologia 83:362-370

Neudecker S (1979) Effects of grazing and browsing fishes on the zonation of corals in Guam. Ecology 60:666-672

Porter JW (1972) Patterns of species diversity in Caribbean reef corals. Ecology 53:745-748

Porter JW (1974) Community structure of coral reefs on opposite sides of the Isthmus of Panama. Science 186:543-545

Porter JW (1976) Autotrophy, heterotrophy, and resource partitioning in Caribbean reef-building corals. Am Nat 110 : $731-742$

Robertson R (1970) Review of the predators and parasites of stony corals, with special reference to symbiotic prosobranch gastropods. Pac Sci 24:43-54

Sammarco PW (1980) Diadema and its relationship to coral spat mortality: grazing, competition, and biological disturbance. J Exp Mar Biol Ecol 45:245-272

Sammarco PW (1982) Echinoid grazing as a structuring force in coral communities: whole reef manipulations. J Exp Mar Biol Ecol 61:31-55

Wellington GM (1982a) An experimental analysis of the effects of light and zooplankton on coral zonation. Oecologia 52:311-320

Wellington GM (1982b) Depth zonation of corals in the Gulf of Panama: control and facilitation by resident reef fishes Ecol Monogr 52:223-241

Submitted: June 30, 1997; Accepted: September 21, 1997 Proofs received from author(s): November 18, 1997 